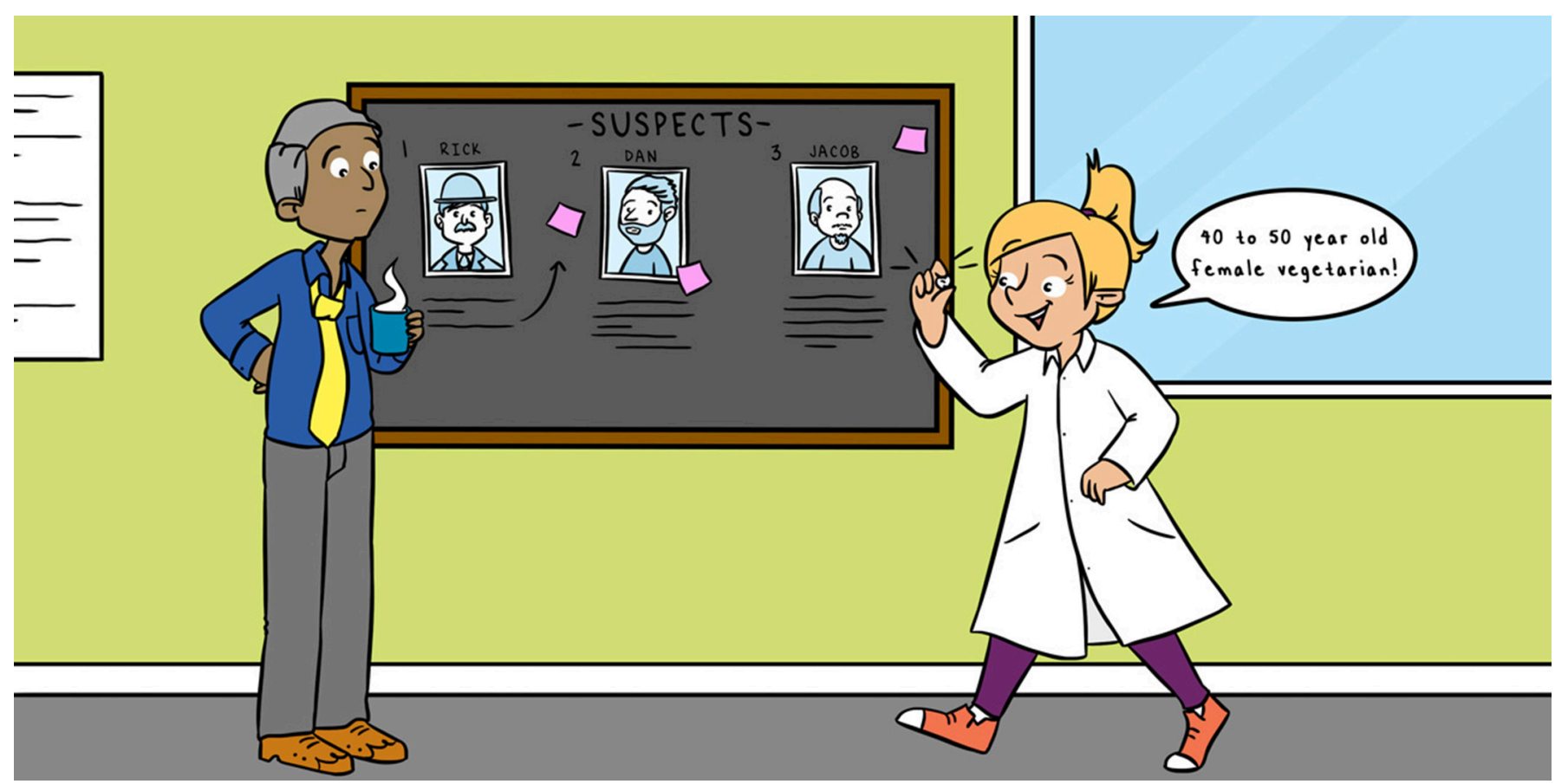

\title{
WHAT TEETH CAN TELL US
}

\section{Klara Janjic ${ }^{1,2^{* t}}$, Fabian Kanz ${ }^{3 t}$ and Hermann Agis ${ }^{1,2 t}$}

${ }^{1}$ Department of Conservative Dentistry \& Periodontology, University Clinic of Dentistry, Medical University of Vienna, Vienna, Austria

${ }^{2}$ Austrian Cluster for Tissue Regeneration, Vienna, Austria

${ }^{3}$ Center for Forensic Medicine, Medical University of Vienna, Vienna, Austria

\section{YOUNG REVIEWERS:}

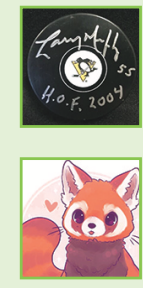

\section{BENJAMIN}

AGE: 14

BREANNA

AGE: 11

1 https://www.researchg ate.net/publication/ 320518472_A_new_ great_ape_with_ startling_resemblances _to_African_members _of_the_hominin_ tribe_excavated_from_ the_Mid-Vallesian_ Dinotheriensande_of_ Eppelsheim_First_. report_Hominoidea_ Miocene_MN_9_ProtoRhine_Riv.
Teeth are the hardest substance of the body and the gatekeeper of the digestive tract. They can survive extreme environmental conditions and they are the last part of the body that is decomposed after death. With these unique features, teeth are often the only remaining body part of a deceased person in a criminal case. Teeth can help investigators to find out who a dead person is, how old the person was, if the person was male or female, what kind of daily habits and lifestyle a person had and how the person died. Thus, the examination of teeth plays a key role in crime scene investigations and can help solve crimes.

\section{INTRODUCTION}

The oldest teeth on earth are almost 10 million years old and were found by researchers in Germany ${ }^{1}$. Imagine the environmental conditions these teeth must have survived over so many years. 
Figure 1

(A) After death, the body soon begins to decompose, leaving the bones and the teeth. Because they can remain intact through years of harsh environmental conditions, teeth are often used to help solve crimes. (B) In a fire, teeth will stay preserved, but can change in color, depending on the temperature of the fire and how long the person was exposed to the fire. (C) In wet or damp environments, the pink teeth phenomenon can sometimes be observed. This happens when blood vessels in the middle of the tooth burst.

\section{ENAMEL}

The outer, visible part of a tooth and the hardest substance in the human body.

\section{FORENSIC}

\section{ODONTOLOGY}

A special field of forensics that analyzes various aspects of teeth. It helps to identify a person and collect information related to a crime.

FORENSIC ANTHROPOLOGY

A special field of forensics that analyzes skeletal remains, including the bones and teeth, of a person involved in a crime.

\section{FORENSICS}

Knowledge from a combination of sciences used to solve a crime.
A Decomposition in different conditions
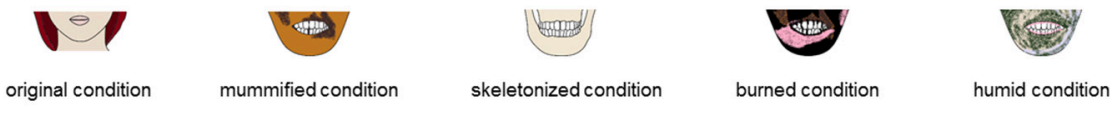

B

Tooth color variations after fire

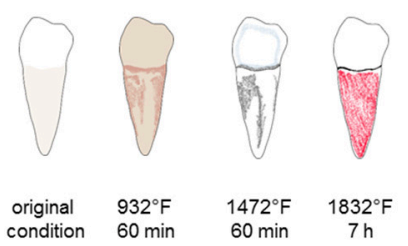

C

Variations of pink teeth

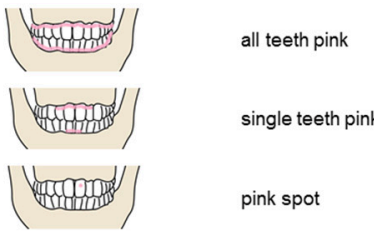

Figure 1

Teeth contain enamel, which is the hardest substance in the human body. They can survive extreme heat, up to $1,600^{\circ} \mathrm{C}\left(=2,912^{\circ} \mathrm{F}\right)$, and they do not mind being under water for a long time. After a person dies, the teeth will be there long after most other body parts have vanished.

These special features of teeth can be useful in some criminal investigations, such as deadly fires, drownings, natural disasters, fatal accidents or crimes in which the body is not found for a long time. In these cases, the human body is skeletonized or mostly decomposed, leaving only the teeth, which can resist exposure to such extreme conditions (Figure 1). The teeth can help to identify a person and to estimate the person's age, sex and health status. Teeth might also tell investigators something about what happened to the body before death.

The fields that deal with these topics are called forensic odontology and forensic anthropology. They are both specialized areas of the field of forensics, which uses knowledge from various sciences to solve crimes. Forensic odontology helps to solve crimes by analyzing special aspects of teeth. Forensic anthropology deals with total skeletonized human remains, including bones and teeth. This article explains how having a closer look at a person's teeth can help to solve crimes.

\section{PERSONAL IDENTIFICATION}

Identifying the victim of a crime is an essential key to solving a criminal case. Most crime investigations require the identity of the victim to be known. For example, searching for important documents from insurance companies, hospitals or police can only be performed if the name of that person is known.

Because every person's teeth are unique, teeth can be used to identify a person. To figure out whose mouth they are looking into, researchers 


\section{Figure 2}

Teeth can be used to determine a person's age. Once a growing tooth breaks through the jawbone (eruption), new lines will appear on the tooth, around the root, each year-like tree rings. Each tooth type erupts at a similar age in every person. Therefore, we can assume an eruption age of 10 for the canine tooth pictured here. By cutting the tooth in half, the lines can be counted under a microscope. Adding the number of counted lines to the age at eruption will provide the person's approximate age at death

\section{CEMENTUM}

A hard substance that is built around the tooth root.

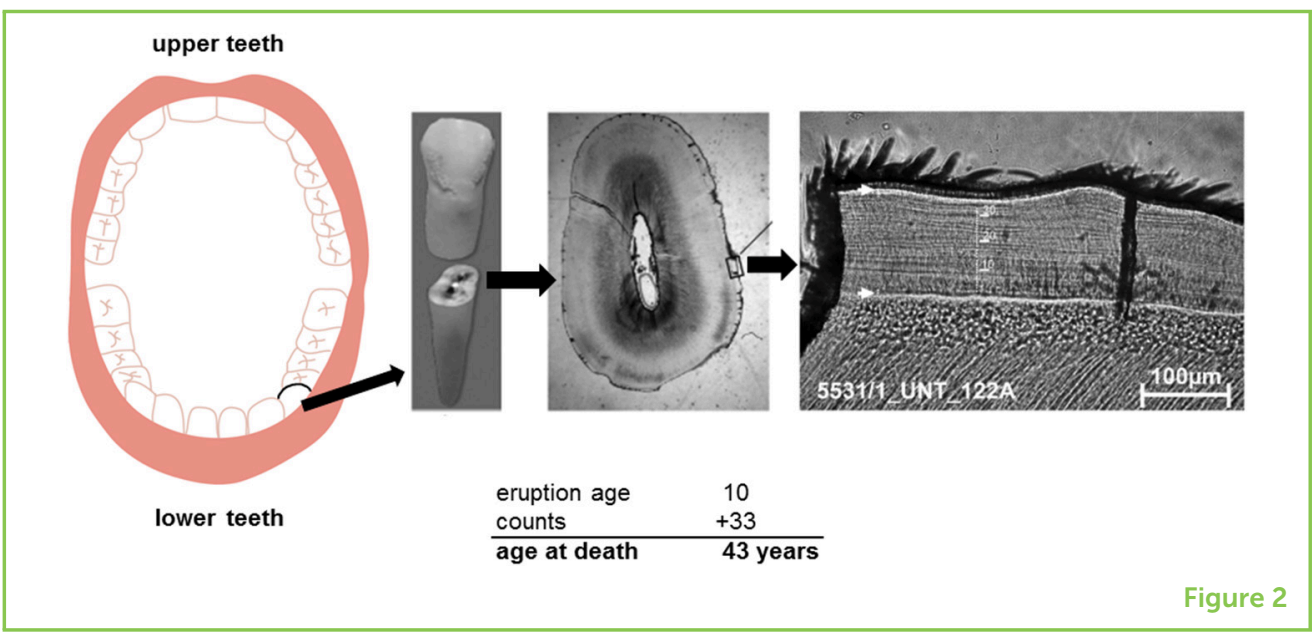

carefully examine several things: the number of teeth that are present, types of teeth (deciduous "baby" teeth or permanent "adult" teeth), positions and orientations of teeth, shapes and sizes of teeth as well as traces of diseases or dental treatments, such as fillings or braces. This detailed description can then be compared with documentation from dentists, to determine the identity of the person [1]. In 1893, records from a dentist helped to identify the murderer of U.S. president Abraham Lincoln [2]. Prior to the examination of the murderer's teeth, people suspected that the wrong person had been executed for Lincoln's murder and that the real murderer was still on the loose. The dental records proved that the suspicion was only a rumor.

\section{AGE ESTIMATION}

As human beings grow up and get older throughout life, teeth grow, change and pass through different stages. Each of these stages has certain unique characteristics, which can help to determine a person's approximate age. The stage of teeth, and thus the age of a person, can be analyzed by looking at a tooth in different ways. In some cases, the tooth stage is visible to the naked eye, while in other cases, it is necessary to have a closer look under the microscope or even to do an $x$-ray [1]. Once a tooth erupts (breaks through from the jawbone) it starts to build two layers of hard tissue called cementum around its root every year [3]. If a cross-section of the tooth root is examined under the microscope, these layers appear as light and dark rings, similar to tree rings. Scientists can count the number of layers and, if they add the eruption year, they will get the person's age at death (Figure 2). Additionally, scientists can perform special chemical tests on teeth to determine a person's age [4]. If a person's identity is unknown, knowing the age of that person already gives an important hint as to who the person could be. Then, only people in a certain age range must be searched for a matching identity. 


\section{CUSPS}

Raised points on the chewing surface of back teeth.

\section{CARIES}

A dental disease caused by insufficient health care. Teeth with caries typically have cavities.

\section{SEX DETERMINATION}

Knowing whether a person is male or female is another big hint toward identifying someone. There are two ways to determine a person's sex with the help of teeth. One way is to analyze shapes and measurements of teeth and the whole skull. Usually, teeth and bone structures of the skull are larger in males than in females and teeth have more cusps (raised points) in females than in males [1]. This is true for many people, but not for all. Therefore, it is important to have a method that can measure the sex of a person more precisely. This can be achieved by examining the DNA from different parts of a tooth. For example, the gene that is needed to produce enamel, the outer layer of a tooth, is produced in different versions in males and females [1].

\section{HEALTH STATUS}

In the body, everything is somehow connected. There are some diseases that do not start in the teeth but that still have some impact on their appearance. For example, people who take certain drugs or those suffering from a lack of vitamin $D$ due to disease, special diets or lack of sunlight can have discolored teeth [1].

Other changes in teeth can come from special diets. For example, enamel of vegetarians will be destroyed more likely than enamel of non-vegetarians. Different countries and cultures have varying access to food and water, both of which can affect the look and health of teeth and give hints to a person's origin. An unbalanced diet can also leave its traces on teeth. For example, if a person does not eat enough food that contains calcium, this person will probably suffer from tooth decay, while a person eating too much sugar is more likely to have caries (cavities).

Analysis of the teeth of Ötzi, the famous iceman mummy, revealed that he had caries, inflamed gums and an injured front tooth. Based on these findings, a Swiss research team determined the iceman's dietary habits, his dental hygiene status and that he was involved in a fight or accident [5]. Other habits can also be spotted on a person's teeth. For example, extensive smoking, drinking coffee or tea and teeth grinding can change the color or appearance of teeth. The procedures used by dentists also differ across the world. In South and Central America, silver and gold materials are still frequently used for tooth treatments, while white materials are preferred in North America, for example [4]. Taken together, these examples demonstrate that teeth can tell investigators some things about a person's daily life, which can be helpful for solving a crime.

\section{PINK TEETH}

Pink teeth are a curious phenomenon in which teeth turn pink after death. The pink color is usually found on the part of the tooth that 
Figure 3

Each person's set of teeth is unique. The combination of number, shapes, sizes, positions, orientations and other individual characteristics of a person's set of teeth results in endlessly possible variations. This information can be used to confirm a person's identity. One's individual tooth pattern can be found directly in the mouth, but also leaves a unique trace in bite marks.

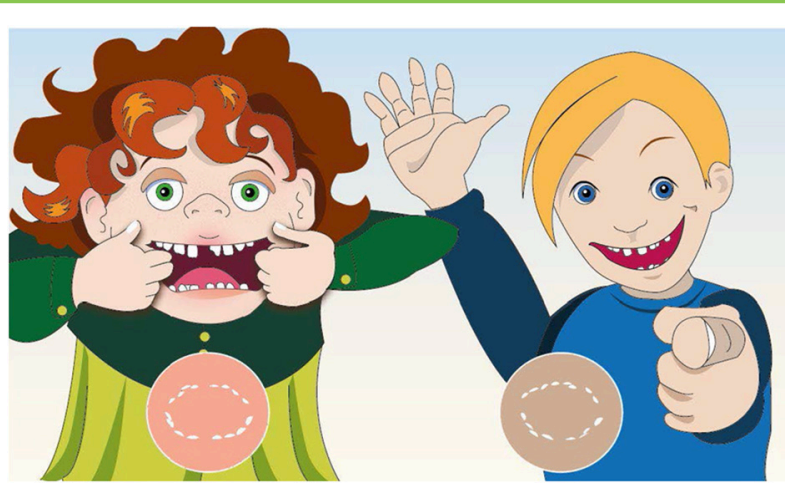

Figure 3

is close to the gums, but it can also appear rarely as a spot in the middle of a tooth. All teeth can be affected, but sometimes only single teeth are affected. The pink discoloration develops when blood vessels in the central part of a tooth burst. Consequently, the red blood pigment is set free and shows through the outer parts of the tooth as pink discoloration. Pink teeth have been seen in dead bodies found in the water, in places with high humidity, in people who died in fires or from suffocation and in bodies that decomposed in wet or damp environments [1]. Although pink teeth preferably appear under these conditions, they cannot be specifically linked to a specific circumstance or disease yet, so it is still uncertain what pink teeth can tell investigators about a person's death.

\section{BITE MARKS}

Biting someone or something leaves an imprint showing the size, shape and arrangement of the biter's teeth (Figure 3). Patterns of missing teeth, tooth gaps and individual tooth shapes can be recognized in bite marks. These patterns can be related to the unique combination of teeth in the person who did the biting. In 1870, a man named Mr. Robinson was accused of the murder of a woman who had multiple bite marks on her arm. The bite marks on the dead woman were compared to the teeth of Mr. Robinson. The court accepted this method and decided that Mr. Robinson was not guilty, because his teeth did not match the bite marks on the murdered woman [2]. Today, bite mark analysis is still used to relate bite marks to either a victim or to a person who committed a crime.

\section{CONCLUSION}

Teeth can tell many things about a person, even long after death, because they can endure extreme conditions for many years. Teeth can tell us about the age, sex, health status and daily life habits of a person. They can also tell us about interactions with other people and possible causes of death. Teeth may even be able to tell us the identity of a person. The clues that teeth can give investigators can 
be important keys to crime scene investigations. In the end, when a criminal case is solved and the victim and cause of death are identified, information obtained from teeth can protect the general public by helping to convict the person who committed the crime. Importantly, this information can also help relatives and friends of the victim to find peace with that person's death. As forensic science continues to advance, teeth may provide investigators with even more critical crime-solving information in the future!

\section{REFERENCES}

1. Balwant, R., and Jasdeep, K. 2013. Evidence-Based Forensic Dentistry. Berlin; Heidelberg: Springer Berlin Heidelberg.

2. Balachander, N., Babu, N. A., Jimson, S., Priyadharsini, C., and Masthan, K. M. 2015. Evolution of forensic odontology: an overview. J Pharm Bioallied Sci. 7:S176-80. doi: 10.4103/0975-7406.155894

3. Naji, S., Colard, T., Blondiaux, J., Bertrand, B., d'Incau, E., and Bocquet-Appel, J. P. 2016. Cementochronology, to cut or not to cut? Int J Paleopathol. 15:113-19. doi: 10.1016/j.jpp.2014.05.003

4. Adserias-Garriga, J., Thomas, C., Ubelaker, D. H., and Zapico, S. C. 2018. When forensic odontology met biochemistry: multidisciplinary approach in forensic human identification. Arch Oral Biol.

87:7-14. doi: 10.1016/j.archoralbio.2017.12.001

5. Seiler, R., Spielman, A. I., Zink, A., and Ruhli, F. 2013. Oral pathologies of the Neolithic Iceman, c.3,300 bc. Eur J Oral Sci. 121(Pt.

1):137-41. doi: 10.1111/eos.12037

SUBMITTED: 13 September 2020; ACCEPTED: 28 June 2021; PUBLISHED ONLINE: 30 July 2021.

EDITOR: Ajithkumar Vasanthakumar, Olivia Newton-John Cancer Research Institute, Australia

CITATION: Janjić K, Kanz F and Agis H (2021) What Teeth Can Tell Us. Front. Young Minds 9:605903. doi: 10.3389/frym.2021.605903

CONFLICT OF INTEREST: The authors declare that the research was conducted in the absence of any commercial or financial relationships that could be construed as a potential conflict of interest.

COPYRIGHT @ 2021 Janjić, Kanz and Agis. This is an open-access article distributed under the terms of the Creative Commons Attribution License (CC BY). The use, distribution or reproduction in other forums is permitted, provided the original author(s) and the copyright owner(s) are credited and that the original publication in this journal is cited, in accordance with accepted academic practice. No use, distribution or reproduction is permitted which does not comply with these terms. 

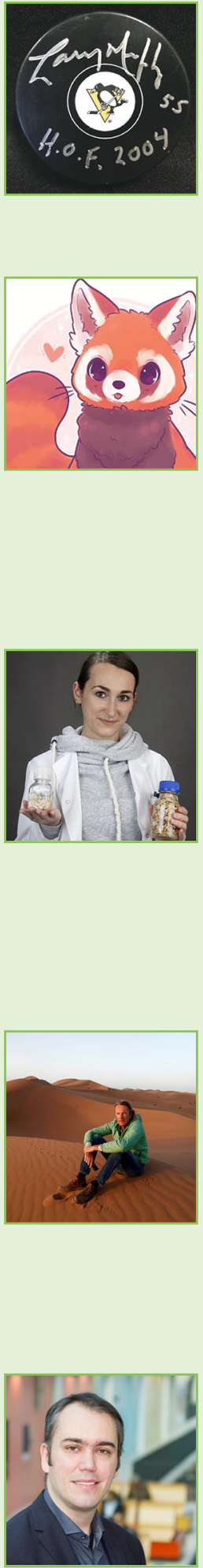

\section{YOUNG REVIEWERS}

BENJAMIN, AGE: 14

When I was introduced into this world, I first lived in an apartment with my dad and mom. Life was great, I had no responsibilities to take care of. Three years later, my sister joined us. After 5 years, I left that apartment to live in a house. This was also when I was introduced to hockey. When I started my middle school, we moved into a giant house, after that our life has been going smoothly.

\section{BREANNA, AGE: 11}

Hello! I am a fifth grader! I am very funny when I am with friends but shy around strangers. I have six friends. I like watching movies, and I read books when I am bored. I like drawing and I love watching on my phone. I have a brother and a helpful mom and dad. My house has a surrounding of many trees and beautiful birds. My favorite foods are ice-cream, banana bread, and pasta. I like being myself!

\section{AUTHORS}

\section{KLARA JANJIĆ}

Klara Janjic is a biomedical scientist at the University Clinic of Dentistry, Medical University of Vienna, Austria. During her doctoral studies, she studied and developed cell culture models and microtissues made from human oral cells, to find out how they could be used for basic research as well as for testing substances or materials. During her time as doctoral student, Klara Janjic also assisted with tasks at the Center for Forensic Medicine in Vienna which is the oldest institution for forensic medicine in the world. Photo: () Nadine Krier. *klara.janjic(ameduniwien.ac.at; †orcid.org/0000-0002-8057-3567

\section{FABIAN KANZ}

Fabian Kanz is an anthropologist and associate professor at the Center of Forensic Medicine, Medical University of Vienna, Austria, where he is the head of the Unit of Forensic Anthropology. Additionally, he is a registered court surveyor for anthropology. Thus, he has a long track record of research in the fields of anthropology, forensics, bones and dentistry. He also helps the judiciary by determining age in living and deceased persons as well as performing identification of people using a wide range of methods. ${ }^{\dagger}$ orcid.org/0000-0001-6720-6781

\section{HERMANN AGIS}

Hermann Agis is a biotechnologist by training and was an associate professor at the University Clinic of Dentistry, Medical University of Vienna in Austria and head of the Competence Center for Tissue Engineering and Cell-Based Therapies. His research focused on oral tissue regeneration. Since the beginning of his career, Hermann Agis supported young scientists in their professions through his involvement in mentoring programs, in the ECTS Academy and as CED-IADR ambassador. Currently, he is the executive director of Fulbright Austria, enabling exchange programs for Austrian and American students, teachers and scientists. ${ }^{\dagger}$ orcid.org/0000-0001-9509-1555 